Meta

Journal des traducteurs

Translators' Journal

\title{
Professional Realism in the Legal Translation Classroom: Translation Competence and Translator Competence
}

\section{Łucja Biel}

Volume 56, numéro 1, mars 2011

URI : https://id.erudit.org/iderudit/1003515ar

DOI : https://doi.org/10.7202/1003515ar

Aller au sommaire du numéro

Éditeur(s)

Les Presses de l’Université de Montréal

ISSN

0026-0452 (imprimé)

1492-1421 (numérique)

Découvrir la revue

Citer cet article

Biel, Ł. (2011). Professional Realism in the Legal Translation Classroom: Translation Competence and Translator Competence. Meta, 56(1), 162-178. https://doi.org/10.7202/1003515ar
Résumé de l'article

L'article a pour objet de décrire les moyens permettant d'intégrer les réalités professionnelles pendant les cours de traduction juridique de premier cycle, avec pour objectif la formation du traducteur tant sur le plan des compétences en traduction que sur celui des compétences professionnelles (distinction établie par Kiraly). Le premier groupe de compétences concerne la capacité de traduire conformément aux normes du marché, le deuxième, celle de fonctionner efficacement sur le marché du travail. Ces compétences sont développées simultanément, mais l'accent est mis sur les compétences en traduction. La conformité aux réalités professionnelles est assurée grâce au choix des textes, authentiques et prototypiques, des branches du droit les plus fréquemment traduites, grâce à des stratégies d'enseignement variées, allant de l'apprentissage de tâches à l'apprentissage par projets, y compris l'approfondissement des savoirs spécialisés et les recherches terminologiques, et, enfin, grâce à des projets de traduction et de révision intégrant les différentes tâches et compétences. 


\title{
Professional Realism in the Legal Translation Classroom: Translation Competence and Translator Competence
}

\author{
LUCJA BIEL \\ University of Gdańsk, Gdańsk, Poland \\ anglb@ug.edu.pl
}

\begin{abstract}
RÉSUMÉ
L'article a pour objet de décrire les moyens permettant d'intégrer les réalités professionnelles pendant les cours de traduction juridique de premier cycle, avec pour objectif la formation du traducteur tant sur le plan des compétences en traduction que sur celui des compétences professionnelles (distinction établie par Kiraly). Le premier groupe de compétences concerne la capacité de traduire conformément aux normes du marché, le deuxième, celle de fonctionner efficacement sur le marché du travail. Ces compétences sont développées simultanément, mais l'accent est mis sur les compétences en traduction. La conformité aux réalités professionnelles est assurée grâce au choix des textes, authentiques et prototypiques, des branches du droit les plus fréquemment traduites, grâce à des stratégies d'enseignement variées, allant de l'apprentissage de tâches à l'apprentissage par projets, y compris l'approfondissement des savoirs spécialisés et les recherches terminologiques, et, enfin, grâce à des projets de traduction et de révision intégrant les différentes tâches et compétences.
\end{abstract}

\begin{abstract}
The paper proposes how to integrate professional realism in BA legal translation classes at the level of translation competence and translator competence. The distinction between competences is adopted from Kiraly, where the former means the ability to translate to the required standard while the latter is the ability to function efficiently as a professional. The competences are developed concurrently, the main focus being placed on translation competence. Professional realism is ensured in content design (the most frequently translated branches of law), a varied selection of authentic and prototypical texts, an eclectic teaching approach progressing from task-based learning to projectbased learning, including subject-field competence building, terminology work and, finally, translation and revision projects which integrate all tasks and activities in a single assignment.
\end{abstract}

\section{MOTS-CLÉS/KEYWORDS}

didactique de la traduction, traduction juridique, réalités professionnelles, compétences en traduction, compétences professionnelles du traducteur

translation pedagogy, legal translation, professional realism, translation competence, translator professional competence

How well do universities train translators for the translation industry? Market research data are not very optimistic. A number of surveys conducted among translation agencies confirm graduates' satisfactory competence as regards language and general translation skills but significant deficiencies in specialized translation and terminology, necessary field knowledge, translation speed, information technology (IT) skills, autonomy, and teamworking (Li 2007: 111; Kiraly 2005: 1099; Ferreira-Alves 2006). ${ }^{1}$ 
Although the situation has markedly improved since the times when specialized translation was slighted by universities as vulgar pragmatism, there still exists a gap between academic training and market needs. The pertinent question arises how trainers may eliminate these deficiencies and reduce the gap to expert translators.

\section{Recent developments on the translation market}

The translation industry itself is developing dynamically in the Internet era. It is impossible for trainers to keep abreast of the changes, which may be grouped into three major categories: professionalization, globalization, and specialization.

- Professionalization: Nowadays translation is commonly regarded as a profession, which is partly due to the recognition of translation studies as a separate discipline at universities. Universities themselves have played a special role in the professionalization of the translator when they took over the training from vocational language schools (Cordero 1994: 171). With the growing number of training programmes, the translator's image has evolved from "mere bilingual typists to highly skilled and multi-skilled professionals" (Kennedy 2000: 440); it has been further enhanced by standardization, such as European Standard EN 15038 Translation services - Service requirement $s^{2}$. In the legal context, Polish sworn translators were for the first time officially recognized as a profession by law in $2004 .^{3}$

- Globalization: The translation market has expanded from local to global. Not so long ago, translators would mainly operate on local markets, delivering their translations in person. With the advent of the Internet and e-mail, geographical boundaries have disappeared and translators have shifted to global teleworking, dealing with a wider variety of clients and assignments.

- Specialization: The market has evolved into higher specialization, which is driven by the growing proficiency in foreign languages, in particular English, among employees. Easier texts are translated in-house by clients themselves while more specialized or technically complex ones are outsourced to translation agencies. First, there is a growing technical complexity of translation processes: "Translation in the context of global markets is concerned with much more than the translation of text," argue Shaw and Holland (2008: 107), providing the example of software being localized into Arabic, which may require a "more flexible user interface design." The second level of complexity concerns the growing specialization of content, which demands from translators a working background knowledge of narrow fields. Most professional sources advise translators not to list too many areas of specialization if they hope to attract clients. The concept of specialization differs in various professional sources: it may be a broad general category or a highly specialized narrow field. For example, the American Translators Association has 11 areas of specialization (Arts and Humanities, Business, Computers, Engineering, Entertainment, Industry and Technology, Law, Medicine, Natural Sciences, Pure Sciences, Social Sciences), each of which is further subdivided. The UK Institute of Translation and Interpretation has as many as 30 main subject areas; ProZ.com ${ }^{4}-9$ general fields and 134 specialty / working fields, while TranslatorsCafé.com ${ }^{5}$ has as many as 150 areas. One of the major general fields is legal translation.

\section{Translation competence and translator competence}

How do these market developments affect our understanding of translation competence and translator training? What is required of a professional translator has mark- 
edly increased and translation competence has been extended by the growing number of relevant skills (see Pym 2003 for discussion). Translation competence has a plethora of definitions ranging from simple to multi-component ones. Rejecting multi-component definitions on methodological grounds (e.g., no empirical evidence, impossibility to keep abreast of market changes), Pym (2003: 489) proposes a minimalist definition - the ability to generate alternative versions of the target text (TT) and select "only one viable TT from this series, quickly and with justified confidence." As Pym (2003: 491) argues, his minimalist definition is in line with Kiraly's understanding of translation competence, that is, the ability to produce a good-quality target text, as opposed to translator competence, which "involves joining a number of new communities such as the group of educated users of several languages, those conversant in specialized technical fields, and proficient users of traditional tools and new technologies for professional interlingual communication purposes" (Kiraly 2000: 13, quoted in Pym 2003: 491). Thus, translation competence is the ability to translate to the required standard while translator competence covers skills required to function as a professional on the market. For the purposes of this paper, I will retain the distinction of translation competence and translator competence.

Translator competence is developed by professionalization of training, in particular simulations of professional practice and traineeships. Following the recent convergence of vocational and academic criteria in training (Caminade and Pym 1998: 283) and the shift of emphasis from general to specialized translation skills (González-Davies and Kiraly 2006: 83), professional realism is present in a number of approaches, such as PATT (Professional Approach to Translator Training; Lobo, Robinson et al. 2007), Gouadec (2007), Kiraly (2005), González-Davies and ScottTennent (2005), Kelly (2005), Pym (2008), and Schäffner (2005). The basic assumption is that training should be practice-oriented; it should correspond to market demands and prepare students for the workplace. The professionalization of training may be achieved through simulations of professional practice: relating teaching to professional environments; role-playing; practising technical aspects of the profession (e.g., invoicing); visits to translation agencies and work placements; real-life projects (Kelly 2005: 75-76).

The next part analyzes how to integrate professional realism in legal translation classes. First, the legal translator profile for the purposes of translator competence should be defined. Legal translation is mainly provided by:

1) Freelance translators working for translation agencies or direct clients;

2) In-house translators in law firms or other business entities;

3) In-house translators in public administration or international institutions, such as the Directorate-General for Translation (DGT) or the European Court of Justice (ECJ) (e.g., lawyer-linguists);

4) (Sworn) translators who work, mostly on a freelance basis, for courts and the police and may require special certification.

To function efficiently on the market, legal translators mainly need technical, teamworking, business and organizational skills; therefore, their translator competence is not markedly different from other specialized translators' competence. It is the translation competence that differs most, and some theoretical models set high requirements. For example, Šarčević's (1997: 113-114) model of the ideal - yet, as she notes, non-existent - legal translator lists basic legal skills, such as thorough knowl- 
edge of legal terminology, legal reasoning and target language (TL) and source language (SL) legal systems, the ability to solve legal problems, analyze legal texts and foresee text construal, drafting skills, basic knowledge of comparative law and methods. Cao's (2007: 41) model consists of translational language competence, translational strategic competence, and translational knowledge structures (subject competence). However, little advice is given on how to achieve such wide-ranging legal translation competence.

In general, there are relatively few publications in English on how to teach legal translation. They include: case studies by Marks (1997), and Aitsiselmi and Trouille (2000); Harvey's (2000) application of Weston's techniques to culture-bound items; Asensio's (2003) discussion of common problems in official translation; Burukina's (2007) use of a deverbalization algorithm as a teaching method; Monzó's (2003) application of a parallel corpus; Northcott and Brown's (2006) collaboration between lawyers and teachers of English for Special Purposes to train European Union (EU) translators; Canadian joint training of law and translation students (Šarčević 1997: 115); Way's (2000) structuring of legal content within a specialized translation course. Although the spectrum of topics is rather broad, these are still isolated studies and more exchanges of best practices are needed to serve as a point of reference or benchmark for legal translation teachers.

Training should address the local and global needs of the legal translation market for a language pair. A different type of training would be required in the case of languages which are used only in monolingual countries (e.g., Polish) than in the case of languages which are also used in multilingual countries (e.g., French), where translated legislation has an authoritative status. Secondly, despite the predominant recommendation to translate only into one's mother tongue (direct translation), there is a large flow of inverse legal translation. As noted by Lonsdale (1998: 65), inverse translation is frequent outside English-speaking countries due to the large number of translations into English and a shortage of English native speakers who know local languages, not least their legal variants. This is in particular true of languages of limited diffusion, for example, Eastern European or Scandinavian languages, which are rarely chosen by learners as a foreign language.

This article applies mainly to the training of specialized translators in monolingual countries with both direct and inverse translation flow. It presents some solutions incorporated in legal translation classes in the bachelor's degree (BA) Bilingual Translation Programme at the University of Gdansk (Poland). The students have general translation competence and are familiar with basic professional issues (e.g., self-employment, translator ethics).

\section{Professional realism in the legal translation classroom}

\subsection{Content design: branches of law to be covered}

Let us have a look at professional sources to see how the macrofield of Law is subdivided into areas of specialization. We consulted the Languages National Training Organisation's National Standards in Translating (LNTO 2001: 65) ${ }^{6}$ and the websites of the Institute of Translation and Interpretation (ITI), the American Translators Association (ATA), <www.proz.com $>$, and <www.translationdirectory.com $>$ (Table 1). 
TABLE 1

Legal translators' areas of specialization

\begin{tabular}{|c|c|c|c|c|}
\hline LNTO & ITI & ATA & ProZ.com & $\begin{array}{c}\text { Translation } \\
\text { Directory }\end{array}$ \\
\hline $\begin{array}{l}\text { - Public law: } \\
\text { legislation, UK } \\
\text { statutory } \\
\text { instruments, EU } \\
\text { directives } \\
\text { - Personal and } \\
\text { commercial law: } \\
\text { deeds, contracts, } \\
\text { wills, trust } \\
\text { documents, } \\
\text { insurance policies, } \\
\text { affidavits }\end{array}$ & $\begin{array}{l}\text { - Civil law } \\
\text { - Commercial } \\
\text { and Company } \\
\text { law } \\
\text { - Criminal law } \\
\text { - International } \\
\text { law } \\
\text { - Motoring law } \\
\text { - Probate and } \\
\text { family law } \\
\text { - Property law }\end{array}$ & $\begin{array}{l}\text { - Banking and } \\
\text { Financial law } \\
\text { - Contracts } \\
\text { - Corporate law } \\
\text { - Patents, } \\
\text { trademarks, } \\
\text { copyrights } \\
\text { - Personal injury } \\
\text { law } \\
\text { - Tax law }\end{array}$ & $\begin{array}{l}\text { - Legal General } \\
\text { Law: contracts } \\
\text { - Law: patents, } \\
\text { trademarks and } \\
\text { copyright } \\
\text { - Law: taxation } \\
\text { and customs }\end{array}$ & $\begin{array}{l}\text { - Banking and } \\
\text { Financial } \\
\text { - General } \\
\text { - Contracts } \\
\text { - Patents / } \\
\text { trademarks } \\
\text { - Taxation / } \\
\text { customs }\end{array}$ \\
\hline
\end{tabular}

As with general fields of specialization, there is no uniform view of subfields within legal translation. Branches which seem most salient are of commercial nature, including contract law, company law, business law, patents and trademarks, tax law. It should be noted that areas of specialization do not necessarily reflect the traditional division of law into branches in a legal system. This is because the areas relate to what is actually translated on the market. Not all branches will be equally translated and prominent in translation practice but those most salient should be accounted for in the content design.

The proposed Legal translation module is split into two courses at the BA level - Introductory legal translation and Certified translation, of 30 hours each - and is followed by the EU translation course (not discussed here). Students may choose more specialized electives in the Master's degree (MA) translation programme. Table 2 presents major branches adjusted to the needs of the Polish-English translation market.

TABLE 2

Major branches covered in the Legal Translation module

\begin{tabular}{|l|l|}
\hline Introductory Legal Translation & General overview of major branches: \\
& - UK, US, and Polish legal system \\
& - Contract law \\
& - Tort law \\
& - Property law \\
& - Employment law \\
& - International law \\
\hline Certified Translation & - Company law \\
& - Criminal law and Criminal procedure \\
& - Civil procedure \\
\hline
\end{tabular}

The first course surveys all the main branches of UK, US, and Polish law, with the narrow focus on contract law. Certified translation, which is regulated by the Polish Act on the Profession of Sworn Translator 2004, is provided for private individuals, business entities (company law), and courts and the police (civil and criminal procedure). 


\subsection{Text selection}

The selection of texts depends on a number of factors, including the training stage, students' background and motivation, translation practice on local / global markets, and language pairs. In order to ensure professional realism texts should be: authentic and prototypical, i.e., representative of translation practice in terms of areas of specialization and text types in adequate proportions. Not all legal genres will be equally represented: focus should be placed on those which are most likely to be commissioned for translation. Less representative text types should not be excluded altogether; awareness of genres, as argued by Alcaraz and Hughes (2002: 103), "is of great assistance to translators since it helps them focus on the particular needs and functions being catered for in a given original, and to look further and deeper into the nature of the particular texts they are dealing with." Table 3 exemplifies text selection for the Legal translation and Certified translation courses. In line with the market demands, the source texts are about equally split into Polish and English of varied origin (UK, US, non-native) and discussed interchangeably.

\section{TABLE 3}

\section{Text selection for the Legal translation module}

\begin{tabular}{|c|c|}
\hline Introductory legal translation & Certified translation \\
\hline $\begin{array}{l}\text { 1. Expert-to-lay communication } \\
\text { - Press article on a court case } \\
\text { - Wiki entry on a legal issue (e.g., torts) } \\
\text { - Victim rights brochure } \\
\text { - Prisoner survey } \\
\text { - Union notice } \\
\text { - Law firm website } \\
\text { - Affidavit }\end{array}$ & $\begin{array}{l}\text { 1. Translation for private individuals } \\
\text { - Birth, marriage and death certificates: birth, } \\
\text { marriage, death certificates, certificate of no } \\
\text { impediment to marriage } \\
\text { - School diplomas } \\
\text { - Employment-related documents: certificate } \\
\text { of employment, P60 end of year certificate, } \\
\text { bank statement } \\
\text { - Last will and testament, living will }\end{array}$ \\
\hline $\begin{array}{l}\text { 2. Contracts } \\
\text { - Letter agreement: software licence } \\
\text { - Loan agreement } \\
\text { - Tenancy agreement } \\
\text { - Non-disclosure agreement } \\
\text { - (Translation) Service provider agreement } \\
\text { - Contract of employment } \\
\text { - Conditions of sale } \\
\text { - Insurance contract } \\
\text { - International treaty }\end{array}$ & $\begin{array}{l}\text { 2. Translation for business entities } \\
\text { - Memorandum and articles of association } \\
\text { - Certificate of incorporation } \\
\text { - Certificate of good standing } \\
\text { - Official company records } \\
\text { - Notarized minutes from the annual general } \\
\text { meeting }\end{array}$ \\
\hline $\begin{array}{l}\text { 3. Expert-to-expert communication } \\
\text { - Legal opinion } \\
\text { - Legislation: Regulation on insurance of } \\
\text { notaries } \\
\text { - Legislation: Road traffic act }\end{array}$ & $\begin{array}{l}\text { 3. Translation for courts, the police, } \\
\text { prosecution service } \\
\text { - Civil and criminal procedure: witness } \\
\text { statements, service, claim forms, particulars } \\
\text { of claim, judgments, etc. } \\
\text { - Petition for divorce, paternity suit, adoption } \\
\text { documents }\end{array}$ \\
\hline
\end{tabular}

The Legal translation course is structured to ensure a gradual progression from expert-to-lay to expert-to-expert communication to raise students' awareness of the recipient and train them as functional translators (Nord 2005: 210). The first part 
offers a varied repertoire of semi-legal texts (expert-to-lay communication) with different functions / skopos and genre conventions. Stylistic variation promotes functionalism: it focuses attention on various degrees of accuracy, creativity and readability, and facilitates a reasoned choice of strategies and techniques. As a result, translation "is no longer the mere transformation of a text from one language to another, but rather the production of a target text that can function within a different context for recipients from a different culture" (Vermeer 1998: 61). For example, translation of an affidavit requires a high degree of accuracy while translation of a law firm website shifts emphasis to its marketing function and requires more creativity. A victim rights brochure brings attention to readability; English brochures are usually reader-friendly compared to more formal Polish brochures despite high functional illiteracy rates for Poland. Following Way's (2000: 137) recommendation to choose a limited rather than a broad number of subfields at introductory specialized translation courses, the main focus was placed on contracts, which are much more frequently assigned in freelance practice than legislation. They range from consumer contracts in plain English, including an informal letter-agreement where the parties are referred to as we and you, to more specialized ones in legalese. Special attention is paid to formulaic repetitive parts of contracts called boilerplate clauses and appropriate adjustment of translation strategies to the governing law clause (Šarčević 1997: 19). The course progresses along what Asensio (2007: 49) calls the vertical axis of specialization from minimally specialized to highly specialized and ends with expert-to-expert communication.

The Certified translation course is split into 3 domains of private, commercial and public nature. In general, certified translation requires high accuracy as it is certified for faithfulness with the source text (ST); however, degrees of accuracy may differ with the purpose of translation. The first component includes texts with a wide array of culture-bound items, such as names of administrative districts, schools, titles, authorities, etc. Harvey's communicative approach based on Weston's techniques allows students to assume "an active role, encouraging them to make reasoned decisions" on the basis of extralinguistic factors (Harvey 2000). The second component focuses on company law and how terms are embedded in conceptual networks (Biel 2009). The final component focuses on translation for the purposes of legal proceedings, where the highest degree of accuracy is required. Interpreting may be used as a warm-up exercise, e.g., sight translation of police reports, witness instructions or statements, grounds for a judgement, all of which are encountered in the oral part of the ministerial examination for sworn translators. The course is assessed by the simulation of the written ministerial exam.

What is useful both in direct and inverse translation training is contrastive textology, that is, working with parallel texts (Hatim 2001: 166; Schäffner 1998: 83) to develop contrastive text competence (Nord 2005: 213). Schäffner (1998: 83) urges the use of parallel texts as an aid in "adapting the target text (TT) to the text-typological conventions of the target culture" and improving quality. This method helps students eliminate translationese - a marked language influenced excessively by the SL. For example, it facilitates finding formulaic expressions (The parties agree as follows, in witness whereof, except as otherwise provided, without prejudice to) or checking the distribution or frequency of collocations (contract entered into / made... rather than the frequent calque from Polish contract signed...). It is an excellent tool 
for non-native speakers but also for non-legally qualified native speakers who are learning specialized variants of their mother tongues.

For this purpose students may use comparable or parallel corpora. In corpusbased translation studies the former is a computerized set of comparable untranslated original texts in two languages (called parallel texts in the translation pedagogy literature cited above) while the latter is a set of source texts with translations (Olohan 2004). Parallel corpora allow students to analyze previous translation solutions, and as noted by Monzó (2003), who describes the application of such a corpus in the legal classroom, they enable the "routinization of the documentation tasks" and raise students' confidence by providing them "with patterns and solutions accepted by clients and the market." However, this method should be used with care on the introductory course to avoid providing students with too many ready-made solutions at the expense of reasoned decisions.

An important element of professional realism is authenticity of teaching materials. As emphasized by Kelly (2005: 119-120), "[c]onsensus in the field is that texts should, as far as possible, be authentic, unmanipulated and presented in their original form," although she justifies minor manipulations at early stages. Texts should be taken from real assignments; however, a legal translator trainer is frequently faced with the confidentiality issue as most assignments are covered by non-disclosure agreements. Authenticity of materials means that they are provided to students on an as is basis, that is:

a) Not only high-quality, well-written texts, but also those which contain various types of errors (logical, terminological and linguistic errors, distorted names, omissions, incomplete sentences, etc.). Students learn that not all source texts are perfect and develop strategies how to work with such texts, which are not so uncommon in commercial practice;

b) English source texts written by non-native speakers (and subject to non-English jurisdiction), e.g., a contract drafted in English by a Polish company and an Italian company;

c) Translation from translation where English functions as a relay language; e.g., a court case documentation translated first from Dutch into English to be translated from English to Polish.

Certain texts may be unlikely to be commissioned in real life but still suitable for other professional purposes. Take for example agreements between translation agencies and freelance translators: service provider agreements, non-disclosure or nonsolicitation agreements. They may naturally introduce students into the world of professional translators - their lingo, financial issues or ethics:

(1) 4. REMUNERATION: The due dates for payment of fees and costs under this Agreement shall not exceed 60 days from Translator's billing for the service. Translation fee: US\$__ per SL word.

Editing fee: US\$__ per TL word.

The above editing fee will include one review of the final formatted document. Translator shall not assess minimum charges or any other fees for that service.

It is not possible to cover all text types students will encounter in their professional lives; hence, they should learn generalizable skills. This depends not only on the content design but also on the delivery of that content, which is discussed below. 


\subsection{Teaching approach}

The pervasive procedure in translator training was the teacher-centred approach described by Ladmiral as the "performance magistrale" or by Kiraly as WTNS, who'll take the next sentence, where the teacher transmits knowledge to a passive student, classes being "largely reduced to homework review" (Kiraly 2005: 1100). This approach has been influenced by the functional turn in translation theory, consisting in reorientation from static linguistic approaches to a dynamic integrative approach, which sees translation as a communicative process (González-Davies and Kiraly 2006: 82). As a result, translation pedagogy observed a shift towards student-centred approaches promoting cooperative and collaborative learning with learner autonomy, where the responsibility for learning is gradually transferred to students (GonzálezDavies and Kiraly 2006: 83). The gradual progression towards the working environment starts

with consciousness-raising activities, instruction proceeds to simulated small-project work and then authentic projects carried out by the students collaboratively but quite independently of the teacher, who may serve as a resource person and project coordinator (González-Davies and Kiraly 2006: 83).

Ideally, trainers should be practising translators with some legal background and pedagogical experience, which is rarely the case. Legal translation may require an initial use of teacher-centred methods and a gradual shift to student-centred ones. The trainer's guidance is crucial at the introductory stage if legal translation is taught to non-legally qualified students.

\subsection{Delivery: methods and procedures}

\subsubsection{Building subject-field competence}

Insufficient knowledge of specialized fields and terminology has been mentioned as one of the major challenges faced by translation graduates (Li 2007: 111; Kiraly 2005: 1099). Knowledge of special fields impacts translation quality, and as argued by Northcott and Brown (2006: 374), translators should "learn to 'think like lawyers' in order to understand legal texts." Students are encouraged to take a postgraduate course or a second major in the subject area they wish to specialize in. In our case they may also attend open lectures at the Faculty of Law. Cao (2007: 46) points to the difference between translators' and lawyers' knowledge: the former have "a considerably high degree of surface knowledge structures in different fields" while the latter tend to have "deep knowledge structures in a particular field." Translators need to know the conceptual content and boundaries of terms and their place in the network (Biel 2009), but their schemata do not have to be filled with so many details. As it is not always possible to provide students with adjusted lectures on comparative law (see Kelly's 2005: 98 practical advice on a lecture on legal systems), it may be necessary to integrate knowledge of special fields into translation classes. Gubby's (2004) English Legal Terminology. Legal Concepts in Language, which provides a theoretical overview of major branches (UK and US legal systems, civil procedure, company law, tort law, company law, EU law, although criminal law/procedure is lacking) followed by comprehension questions and monolingual glossaries, is useful for this purpose 
as well as for self-study. Another suitable textbook adjusted to translator training is Alcaraz and Hughes' Legal Translation Explained (2002), especially chapters 3 and 4 on the English legal system and civil and criminal proceedings.

Teaching students SL and TL terminologies is seen by Kennedy (2000: 440) as one of the remedies for the legal translation industry. She emphasizes, "[t]he translator needs legal training and familiarity with both countries' legal vocabularies in order to grasp each meaning and ensure that the two legal concepts correspond" (Kennedy 2000: 425). It is also important to raise students' awareness of terms: they are often unable to recognize that a lexical item is a term, especially when it is polysemous and has a more general meaning as well as a specialized legal meaning (Northcott and Brown 2006: 362). This may cause critical errors, e.g., fixed charge tends to be automatically translated as stała opłata (fixed-rate fee) when it may also mean zastaw rejestrowy (registered pledge).

Subject competence and terminology skills may be improved, inter alia, through bilingual terminology tests focused on separate branches of law. Thanks to the narrow focus, tests enable the students to build connections between concepts in a given field and locate them in the conceptual network. Expert translators have well-developed connections between internalized concepts in contrast to novice translators, whose knowledge seems to be less interconnected; as a result, expert translators tend to process information globally while novices do so locally. As TAP research shows, the gap between expert and novice translators consists not only in the processing speed but also in the quality of processing ("higher-level mental representations and higher-level organization and integration of subprocesses," Jakobsen 2005:187). One of the books useful for this purpose is Penguin's Test Your Professional English: Law by Brieger $(2002)^{7}$, which is divided into eight conceptual fields (English legal system, contract law, company law, criminal law, property and tort law, employment law, alternative dispute resolution (ADR), international law). Testing itself may be regarded as a teacher-centred method; however, the internalization of basic vocabulary is critical to ensure naturalness and efficiency of the translator's work and to avoid lexicalization problems. Students are not given lists of terms and equivalents to memorize but are asked to identify terms in the test book and find their Polish equivalents using monolingual and bilingual dictionaries and online resources (by googling or viewing terminological discussions at <www.proz.com>'s KudoZ and $<$ www.translatorscafe.com>'s TCTerms; Biel 2008). In this way they practise research skills and learn how to evaluate reliability of sources. In the Legal translation course the students are tested systematically once per week for 8 consecutive weeks; a test lasts 15 minutes and consists of a number of vocabulary exercises and a translation (without dictionaries) of 2-3 sentences that appear in the tested chapter. The vocabulary exercises include providing an equivalent of a Polish or English term or explaining the meaning of a term (e.g., equity, homicide, letter of credit, money laundering, peace bond) or a difference between two similar terms (libel vs slander, compensatory vs punitive damages, partnership vs company, memorandum vs articles of association). It is important to ask students for the conceptual content of a term since on average subject competence is low; they know that the equivalent of Polish akredytywa is letter of credit but have problems explaining what it means. A short translation during the tests markedly increases translation speed and at the end of the course nearly all students meet the time limit of the in-class translation test (about 300 words of a 
legal text within 1.5 hours). They also have improved grades in the terminology category compared to those obtained before the testing phase. Faster translation speed is important for students who want to take the ministerial sworn-translator examination with demanding time limits (about 300 words within 1 hour).

In the Certified translation course learners are given more autonomy and tests are replaced by small projects where students collaboratively prepare bilingual glossaries for subfields of civil and criminal procedure on the basis of contextualized chapters from Gubby (2004), Alcaraz and Hughes (2002), or Rossini (1999). Rather than drafting bilingual alphabetical lists of terms with equivalents, students may organize terms in networks by drawing conceptual maps or flow charts (scenarios) and gloss equivalents with additional information: SL-oriented or TL-oriented, UK / US / Canadian, degree of incongruity, frequent collocations. Glossaries may be prepared in Excel, Access or MultiTerm to practise technical skills.

\subsubsection{From task-based learning to project-based learning}

Some attention should be devoted to consciousness-raising activities that improve comprehension and foster global rather than local processing (Tables 4, 5 and 6). The objective is to help students automate processes that seem to be routine in expert translators (Colina 2003: 42).

TABLE 4

\section{Pre-translation activities}

\begin{tabular}{|c|c|}
\hline $\begin{array}{l}\text { Writing for } \\
\text { translation / } \\
\text { controlled } \\
\text { writing }\end{array}$ & $\begin{array}{l}\text { Preparing a press release on the basis of case documentation, drafting a contract; revision } \\
\text { of faulty or machine-translated texts (Nord 2005: 213; Pym 2008: 8); summarizing legal } \\
\text { texts in the SL; intralinguistic translation: "rewriting texts for other audiences, purposes, } \\
\text { media, places, etc." (Nord 2005: 212), i.e., rewriting a contract or will into plain English, } \\
\text { drafting a brochure that explains a legislative passage (shift from the language of law to } \\
\text { semi-legal language). }\end{array}$ \\
\hline $\begin{array}{l}\text { Synoptic } \\
\text { translation }\end{array}$ & $\begin{array}{l}\text { It is advocated by Gouadec (2007) at the beginning of training: summarizing selected } \\
\text { clauses of a contract or legislative sections in the target language; summarizing improves } \\
\text { comprehension and helps discriminate critical from less important information. }\end{array}$ \\
\hline ST analysis & $\begin{array}{l}\text { Examples of ST analysis (see Nord 2005: } 212-213 \text { for more activities): } \\
\text { - Reading comprehension: asking questions to check comprehension, e.g.. What is the } \\
\text { function of Waiver, Severability or Entire Agreement clauses? Some time may be devoted to } \\
\text { complex syntactic features of legalese, such as the notorious sentences in the UK memoran- } \\
\text { dum of association where an object is separated from the verb by a long string of adverbials } \\
\text { without punctuation: to secure by mortgage charge or lien on the whole or any part of the } \\
\text { Company's undertaking and property (whether present or future) including its uncalled } \\
\text { capital the discharge by the Company or any other person of any obligation or liability. } \\
\text { - Analysis of macrostructure and microstructure (Annex C, EN 15038 2006), e.g., } \\
\text { identification of genre, text function and type, rhetorical patterns, recipients, ambigui- } \\
\text { ties, and selection of translation strategies. } \\
\text { - Identification of critical parts in the text to "cultivate awareness of risk distribution" } \\
\text { (Pym 2008: 8): e.g., normative parts in the legislation; personal data in certificates; } \\
\text { references to contractual parties which bear phonetic resemblance: Ubezpieczyciel } \\
\text { (Insurer), Ubezpieczający (Policyholder), Ubezpieczony (Insured); Lessor } \\
\text { (Wynajmujący), Lessee (Najemca). } \\
\text { - Identification of potential problems in the source text: empirical research shows that } \\
\text { novices are unaware of translation problems, interferences and areas that need checking } \\
\text { (Colina 2003). Colina (2003) as well as Aitsiselmi and Trouille (2000) recommend asking } \\
\text { students to identify problem areas in an ST before they prepare its translation at home } \\
\text { and next to discuss their solutions in groups. }\end{array}$ \\
\hline $\begin{array}{l}\text { Research for } \\
\text { translation }\end{array}$ & $\begin{array}{l}\text { Search for parallel texts, background information, legislative definitions of relevant terms, } \\
\text { evaluation of reliability of information sources }\end{array}$ \\
\hline
\end{tabular}


TABLE 5

Translation activities

\begin{tabular}{|l|l|}
\hline $\begin{array}{l}\text { Translation for } \\
\text { various audiences }\end{array}$ & $\begin{array}{l}\text { For example: translation for lay / expert or US / UK audience, brochure } \\
\text { translated for Poles living in Poland / the UK. }\end{array}$ \\
\hline $\begin{array}{l}\text { Translation } \\
\text { adjusted to the } \\
\text { client's } \\
\text { specifications }\end{array}$ & $\begin{array}{l}\text { Reference materials provided by the client, i.e., ensuring consistency with a } \\
\text { previous translation of a contract, updating the existing translation, } \\
\text { conformity with the style guide or client glossaries. }\end{array}$ \\
\hline $\begin{array}{l}\text { Translation with } \\
\text { commentary }\end{array}$ & $\begin{array}{l}\text { An assignment to make students reflect on, discuss and justify their translation } \\
\text { decisions and progress towards conscious competence. }\end{array}$ \\
\hline
\end{tabular}

TABLE 6

\section{Post-translation activities}

\begin{tabular}{|l|l|}
\hline Self-check & Checking for accuracy, linguistic correctness, readability \\
\hline $\begin{array}{l}\text { Bilingual revision } \\
\text { by peers }\end{array}$ & $\begin{array}{l}\text { Checking the TT against the ST for accuracy, terminology consistency, } \\
\text { register and style (EN 15038 2006) using the Track Changes or Comment } \\
\text { function; writing a revision report in a constructive style or filling in } \\
\text { professional quality report sheets (Kelly 2005: 108), such as the LISA form } \\
\text { with the classification of errors. NB.: Bilingual revision by a second translator } \\
\text { is the professional standard both in the European norm EN 15038 (2006) and } \\
\text { the UK National Standards in Translating (LNTO 2001: 68). }\end{array}$ \\
\hline $\begin{array}{l}\text { Monolingual } \\
\text { review by peers }\end{array}$ & $\begin{array}{l}\text { Checking the TT for readability, native update of the translation. Both revision } \\
\text { and review raise students' understanding of translation quality and errors. }\end{array}$ \\
\hline
\end{tabular}

The activities described above aim at developing translation competence. They may be done individually or, to practise teamwork, in pairs and small groups (Kelly 2005: 102, on teamwork organization). Teamworking has been recognized as essential for success in future professional life (Lobo, Robinson et al. 2007: 519); as projects get more complex, "teamwork becomes the reality in the translation landscape" (Thomson-Wohlgemuth and Thomson 2004: 266). It also applies to legal translators, in particular those who work in international institutions or as in-house translators in law firms. Other elements of translator competence may be integrated into these activities:

- Formatting: texts are provided in their original layout in a PDF file (scanned certificates, diplomas, etc.), and students are asked to recreate their original format in translation;

- Deadlines: Assignments have strict deadlines and have to be uploaded on the Moodle platform, which is set to prevent late submissions; students learn how to plan their time to meet the deadline;

- Preparing quotations for translation and invoicing;

- Discussions on field-specific professional issues: how to certify a translation; how to describe a document, seals and stamps, signatures for certification purposes; what may be omitted in a certified translation; agencies' pressure to provide signed blank pages with certification.

In the classroom environment, translator competence is fully developed in project-based learning. This approach has been advocated in a number of recent publications (Gouadec 2007; Kiraly 2005; Pym 2008; Lobo, Robinson et al. 2007), given the growing complexity of translation projects: "the challenge for the transla- 
tion services industry is in managing the complexity of stakeholders, processes, data structures, timescales and content types" (Shaw and Holland 2008: 110). Projects are "multicompetence assignments" (González-Davies and Scott-Tennent 2005: 170) as they develop a wide array of professional skills ranging from teamworking to other roles, such as reviser, proofreader, DTP (Desktop Publishing) checker, project manager, terminologist, tester, and account manager. As emphasized by Pym (2008: 8), "all students should be trained in neighboring skills, not just to enhance employability but also so they can understand their place within large translation activities." This approach positions translation as part of a larger whole, a project cycle. To ensure maximum results real-life projects commissioned by real and paying clients should be used (Kelly 2005: 76).

Projects should also be used in the legal translation classroom, even though it may be rather difficult to find real-life projects for confidentiality reasons, except for less professionally real genres, such as legislation or semi-legal texts: brochures, a Wiki entry, a website of a non-profit organization or local authorities. To work on more prototypical genres, such as contracts or case documentation, simulation may be necessary. In the courses discussed we use short projects of up to 5,000 words which are complementary to other activities. Fully-fledged longer and more technically complex projects span a single course at the MA level; for example, Gouadec's projects (2003: 16) consist of 200 pages translated by students during his class over the academic year.

Projects are "students' initiation into the professional world" (González-Davies and Kiraly 2006: 83). In a project students act as a translation agency, assigning themselves rotating roles: project manager, translators, proofreaders, terminologist, desktop publisher, etc. Students are encouraged to use group communication tools, e.g., e-mails, instant messengers, Skype and the Moodle platform. If possible, students of law may be involved in the revision phase or as consultants while in the case of inverse translation, collaboration with native speakers would be fruitful. Table 7 shows an example of tasks students are expected to carry out (see Gouadec 2007; Lobo, Robinson et al. 2007: 523).

\section{TABLE 7}

\section{Translation Project Cycle}

\section{TRANSLATION PROJECT CYCLE}

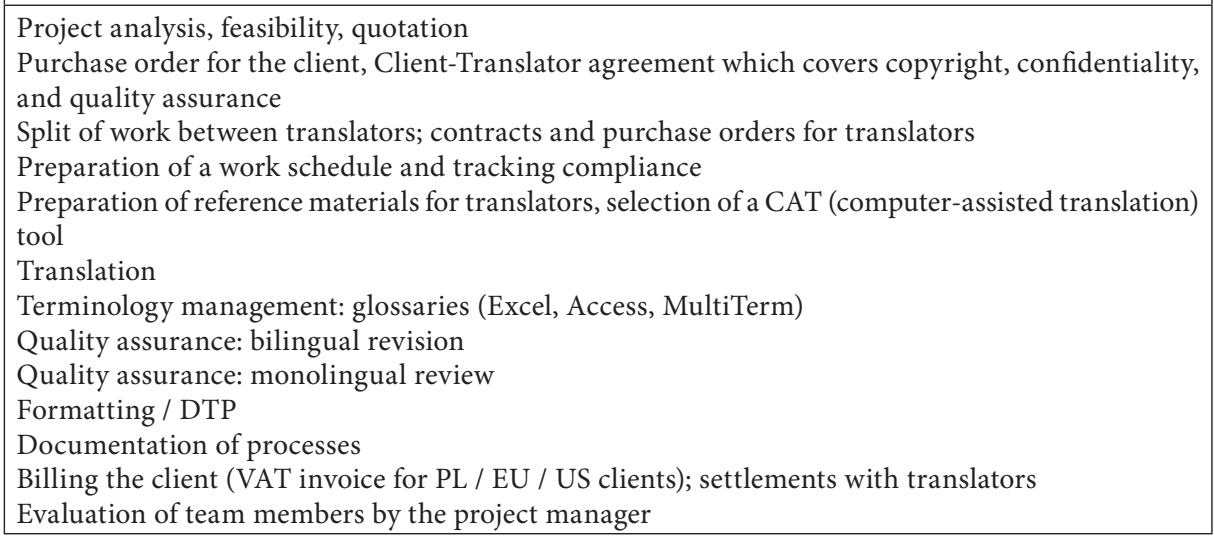


One of the additional major advantages for translation competence is that a project involves a complete longer text rather than excerpts which are usually discussed during classes. It helps to focus on more complex textual phenomena, such as cohesion, coherence, consistency of terminology and quality or unity of style. Our observations show that in individual assignments of 300-600 words students rarely have problems with terminology consistency. When working in a team on a longer text, more consistency problems arise, even though students are asked to make sure that their component translation is consistent with other team members' translations.

Projects ensure learner autonomy and result in increased motivation. Students learn from each other: after project assignments it was noted that 20 per cent of lower-performing students improved their translation competence in later individual assignments. In general, students find projects enjoyable, supportive and practical. The shortcomings indicated by students working on their first project were as follows: more difficult than it seemed at first, more time-consuming, difficult to coordinate, difficult to ensure consistency, problems with some passive team members. Furthermore, projects offer a holistic approach by integrating a number of skills used simultaneously by professional translators in real life: translation, technical skills, business skills (project planning and management, quoting, invoicing, taxes, documentation, customer relation management). As emphasized by Lobo, Robinson et al. (2007: 519), "[c]ompartmentalizing learning into course modules with only minimal coordination of teaching does not allow for an overall view of the full task within a professional process."

Translation competence and translator competence should therefore be developed concurrently, albeit at varied degrees. We agree with Kelly (2005: 119) that professional realism "should be carefully combined with progression in the learning process" and becomes more important at later stages of training, while early stages should focus on translation competence. Translator competence is an important factor in reducing the shock students may face in the real world but it should not be trained at the expense of absolutely fundamental translation competence. As aptly noted by Mossop (2003: 20):

Nowadays one constantly hears that what students really need are skills in document management, software localization, desktop publishing and the like, I say, nonsense. If you can't translate with pencil and paper, then you can't translate with the latest information technology.

\section{NOTES}

1. In her survey of administrators of translation services Li (2007: 111) found that major challenges faced by new recruits in Hong Kong were: insufficient field knowledge (70\%) and specialized terminologies (61\%), inadequate translation skills (48\%), low translation speed (36\%). Sponsored by the International Federation of Translators (FIT), the survey of the Italian market mentions dissatisfaction with specialized translation, terminology management, IT skills, autonomy, and teamworking, while the Canadian survey listed low professional skills (quoted in Kiraly 2005: 1099). Similar findings were obtained by Ferreira-Alves (2006) in his survey of Portuguese translation companies.

2. EN 15038:2006 Translation services - Service requirements (2006). Brussels: European Committee for Standardization.

3. Poland's sworn translators (tłumacz przysięgły) are regulated by the Act of 25 November 2004 on the Sworn Translator Profession. Sworn translators are certified to provide notarized translations to courts and other public institutions, business entities, and private individuals, as well as to provide interpreting in prescribed official situations (judicial proceedings, police interrogations, 
notarial transactions, weddings, etc.). Eligible candidates, who have a clean criminal record, a master's degree in languages or a master's degree in another field and a postgraduate translation / interpreting course diploma, take a combined written and oral examination organized by the Ministry of Justice. The written part consists of four legal texts to be translated from and into Polish while the oral part checks consecutive interpreting (2 recordings to be interpreted from Polish) and sight translation (2 texts to be translated into Polish). Currently, there are more than 10,000 sworn translators in Poland.

4. ProZ.com: <http://www.proz.com>, visited on 12 November 2010.

5. TranslatorsCafé.com: <http://www.translatorscafe.com>, visited on 12 November 2010.

6. Languages National Training Organisation (2001): The National Standards in Translating. London: LNTO.

7. Brieger, Nick (2002): Test Your Professional English: Law. Penguin English Guides. Harlow: Longman.

\section{REFERENCES}

Aitsiselmi, Farid and Trouille, Helen (2000): Legal translation in the classroom, a case study. In: Tradulex.org. Genève 2000: Actes. La traduction juridique. Histoire, théorie(s) et pratique. (17-19 February 2000). Visited 12 December 2008, <http://www.tradulex.org>.

Alcaraz, Enrique and Hughes, Brian (2002): Legal Translation Explained. Manchester: St. Jerome.

Asensio, Roberto Mayoral (2003): Translating Official Documents. Manchester: St. Jerome.

Asensio, Roberto Mayoral (2007): Specialised translation. A concept in need of revision. Babel. 53(1):48-55.

BIEL, Łucja (2008): Legal terminology in translation practice: dictionaries, googling or discussion forums? SKASE Journal of Translation and Interpretation. 3(1):22-38. Visited 29 December 2008, <http://www.skase.sk/Volumes/JTI03/pdf_doc/BielLucja.pdf>.

BIEL, Łucja (2009): Organization of background knowledge structures in legal language and related translation problems. Comparative Legilinguistics. International Journal for Legal Communication. 1:176-189.

BurukinA, Olga A. (2007): Legal translation: algorithm for the beginner in the Russian language realities. In: Danuta Kierzkowska, ed. Court Interpreting and Legal Translation in the Enlarged Europe 2006. Warsaw: Translegis, 90-98.

Caminade, Monique and Рyм, Anthony (1998): Translator-training institutions. In: Mona BAKER, ed. Routledge Encyclopedia of Translation Studies. London: Routledge, 280-285.

CAO, Deborah (2007): Translating Law. Clevedon: Multilingual Matters.

Colina, Sonia (2003): Towards an empirically-based translation pedagogy. In: Brian BAER and Geoffrey S. КовY, eds. Beyond the Ivory Tower. Rethinking Translation Pedagogy. Amsterdam: John Benjamins, 29-59.

CORDERO, Anne (1994): The role of the university in the professionalization of the translator. In: Deanna L. Hammond, ed. Professional Issues for Translators and Interpreters. American Translators Association Scholarly Monograph Series VII. Amsterdam: John Benjamins, 171-179.

Ferreira-Alves, Fernando (2006): Linking professional practice with translation training in a business-oriented setting: The Portuguese Association of Translation Companies example. Visited 29 December 2008, <http://hdl.handle.net/1822/7174>.

González-Davies, Maria and Kiraly, Don (2006): Translation: Pedagogy. In: Keith Brown, ed. Encyclopedia of Language and Linguistics. Oxford: Elsevier, 81-85.

González-Davies, Maria and Scott-Tennent, Christopher (2005): A problem-solving and student-centred approach to the translation of cultural references. Meta. 50(1):160-179.

GouAdEC, Daniel (2003): Notes on translator training (replies to a questionnaire). In: Anthony Рyм, Carmina FalladA, José Ramón Biau, et al., eds. Innovation \& E-Learning in Translator Training. 11-19. Visited 29 December 2008, <http://isg.urv.es/library/papers/innovation_book.pdf>. 
Gouadec, Daniel (2007): Translation as a Profession. Amsterdam: John Benjamins.

GubBy, Helen (2004): English Legal Terminology. Legal Concepts in Language. The Hague: Boom Juridische uitgevers.

Harvey, Malcolm (2000): A beginner's course in legal translation: the case of culture-bound terms. In: Tradulex.org. Genève 2000: Actes. La traduction juridique. Histoire, théorie(s) et pratique. (17-19 February 2000). Visited 12 December 2008, <http://www.tradulex.org>.

Hатім, Basil (2001): Teaching and Researching Translation. Harlow: Longman.

JAKоBSEN, Arnt Lykke (2005): Investigating expert translators' processing knowledge. In: Helle V. Dam, Jan Engberg and Heidrun Gerzymisch-Arbogast, eds. Knowledge Systems and Translation. Text, Translation, Computational Processing [TTCP] 7. Berlin: Mouton de Gruyter, 173-189.

Kelly, Dorothy (2005): A Handbook for Translator Trainers. A Guide to Reflective Practice. Manchester: St. Jerome.

Kennedy, Rose (2000): Much ado about nothing: Problems in the legal translation industry. Temple International and Comparative Law Journal. 14(2):423-444.

Kiraly, Don (2000): A Social Constructivist Approach to Translator Education. Empowerment from Theory to Practice. Manchester: St Jerome

Kiraly, Don (2005): Project-Based Learning: a Case for Situated Translation. Meta. 50(4):10981111.

LI, Defeng (2007): Translation curriculum and pedagogy: Views of administrators of translation services. Target. 19(1):105-133.

Lobo, María Dolores Olvera, Robinson, Bryan, Prieto, Rosa María Castro, et al. (2007): A professional approach to translator training (PATT). Meta. 52(3):517-528.

Lonsdale, Allison Beeby (1998): Direction of translation (directionality). In: Mona BAKER, ed. Routledge Encyclopedia of Translation Studies. London: Routledge, 63-67.

Marks, Margaret (1997): Teaching German-English legal translation to German students of translation. Translation Journal. 2(1). Visited 12 December 2008, <http://accurapid.com/ journal/02wkshop.htm>.

Monzó, Esther (2003): Corpus-based Teaching: The Use of Original and Translated Texts in the training of legal translators. Translation Journal. 7(4). Visited 12 December 2008, <http:// accurapid.com/journal/26edu.htm>.

Mossop, Brian (2003): What should be taught at translation school? In: Anthony Pyм, Carmina Fallada, José Ramón BiAU, et al., eds. Innovation \& E-Learning in Translator Training. 20-22. Visited 29 December 2008, <http://isg.urv.es/library/papers/innovation_book.pdf >.

Nord, Christiane (2005): Training functional translators. In: Martha Tennent, ed. Training for the New Millennium. Pedagogies for translation and interpreting. Amsterdam: John Benjamins, 209-223.

Northсотт, Jill and Brown, Gillian (2006): Legal translator training: Partnership between teachers of English for legal purposes and legal specialists. English for Specific Purposes. 25(3):358-375.

Olohan, Maeve (2004): Introducing Corpora in Translation Studies. London: Routledge.

Pyм, Anthony (2003): Redefining Translation Competence in an Electronic Age. In Defence of a Minimalist Approach. Meta. 48(4):481-497.

Рyм, Anthony (2008): Professional corpora: Teaching strategies for work with online documentation, translation memories, and content management. Chinese Translators' Journal. 29(2):41-45. Visited 12 December 2008, <http://tinet.org/ apym/on-line/translation/2008_ professional_corpora.pdf>.

RossinI, Christine (1999): English as a Legal Language. London: Kluwer Law International.

ŠArČEvić, Susan (1997): New Approach to Legal Translation. The Hague: Kluwer Law International.

SChäffner, Christina (1998): Parallel Texts in Translation. In: Lynne Bowker, Michael Cronin, Dorothy Kenny, et al., eds. Unity in Diversity? Current Trends in Translation Studies. Manchester: St. Jerome, 83-90. 
SCHÄFfner, Christina (2005): Preparing students of translation for the real world: Needs, methods, constraints. In: Jean Peeters, ed. On the Relationships Between Translation Theory and Translation Practice. Frankfurt: Peter Lang, 237-248.

Shaw, Duncan R. and Holland, Christopher P. (2008): Strategy, networks and systems in the global translation services market. In: Peter H.M. Vervest, Diederik W. van Liere, and Li ZHeng, eds. The Network Experience - New Value from Smart Business Networks. Berlin: Springer-Verlag, 99-118.

Thоmson-Wohlgemuth, Gaby and Thомson, Ian (2004): Acquiring capabilities in translation. Towards a model of translation business. Target. 16(2):253-287.

Vermeer, Hans J. (1998): Didactics of translation. In: Mona BAKer, ed. Routledge Encyclopedia of Translation Studies. London: Routledge, 60-63.

WAy, Catherine (2000): Structuring specialized translation courses: a hit and miss affair? In: Christina SCHÄFFNER and Beverly ADAB, eds. Developing Translation Competence. Amsterdam: John Benjamins, 131-142. 